Research paper

\title{
Mean height or dominant height - what to prefer for modelling the site index of Estonian forests?
}

\author{
Toomas Tarmu*, Diana Laarmann and Andres Kiviste
}

Tarmu, T., Laarmann, D., Kiviste, A. 2020. Mean height or dominant height - what to prefer for modelling the site index of Estonian forests? - Forestry Studies | Metsanduslikud Uurimused 72, 121-138, ISSN 1406-9954. Journal homepage: http:/ / mi.emu.ee/forestry.studies

\begin{abstract}
The availability of a large amount of data from reliable sources is important for forest growth modelling. A permanent plot where trees are repeatedly measured provides a clearer picture of stand alterations. Various factors, including forest management, affect forest growth and accuracy of its assessment. In Estonia, mean height as a regression height prediction at mean square diameter is commonly used in forest management practice. Alternatively, dominant height can be used. The main advantage of using dominant height instead of mean height is that the growth of dominant trees is not so strongly affected by stand density (thinning). The aim of our research was to investigate the difference between mean height and dominant height when used as stand height. The research was based on the Estonian Network of Forest Research Plots (ENFRP). As a result, we found that the average mean height change was significantly greater in the case of thinning when compared to undisturbed stand development, whereas, the average dominant height change in the case of thinning compared to undisturbed development was less significant. As a side result, we developed a regression model that can be used for calculating the dominant height of the main tree species using stand attributes (mean height, quadratic mean diameter and density) with a residual standard deviation of $0.466 \mathrm{~m}$.
\end{abstract}

Key words: top height, stand height growth, permanent plot, thinning, growth model.

Authors' addresses: Chair of Forest Management Planning and Wood Processing Technologies, Institute of Forestry and Rural Engineering, Estonian University of Life Sciences, Kreutzwaldi 5, 51006 Tartu, Estonia, *e-mail: toomas.tarmu@emu.ee

\section{Introduction}

Quantitative information on stands and trees is needed for assessment of available forest resources and forest management planning (Burkhart \& Tomé, 2012). A consistent and reliable flow of forest growth information is necessary for the development of an accurate mathematical model (Kiviste \& Hordo, 2002). Mathematical models will provide valuable insight for resource estimations, management option exploration and silvicultural alternatives (Vanclay, 1997). Information in the form of raw data can be collected from forest sample plots, which can be either permanent or temporary (Räty \& Kangas, 2019). Permanent plots are repeatedly measured with intervals while temporary plots are measured once. Modelling forest growth using temporal sample plots can give distorted results, as it does not provide information on each individual tree over time (Gadow \& Hui, 1999). Permanent sample 
plots where trees are individually and permanently marked for repeated measurements are a better choice for forest growth modelling (Picard et al., 2010). However, establishing and maintaining permanent plots with continuous measurements is expensive (Allen, 1993).

Stand development is a continuously evolving process that requires more realistic and functional prediction methods in order to estimate sufficiently close to real values. Various factors, including forest management, can change forest growth and accuracy of its assessment. Roughly 40\% of Estonian forests belong to the Estonian state and are largely maintained, grown and managed (thinned) by the State Forest Management Centre. Thinning is used in forest management as a tool for regulating tree competition and give an advantage to the select remaining trees (Pretzsch, 2009). Thinning studies have consistently shown an increase in individual tree diameter and volume growth with decreasing stand density (Mäkinen \& Isomäki, 2004; Kim et al., 2016). The main reason for the widespread use of thinning in forestry management is its economic benefit.

Forest stand height, which is an important variable in forest growth modelling, can be defined either as mean or dominant stand height. Mean height can be estimated as an arithmetic average of all trees in a stand or as mean height weighted in proportion to their basal area (also known as Lorey's mean height) (Lorey, 1878). However, in this study we calculated mean height as a regression height prediction at mean square diameter, as it is the most commonly used method in Estonia (Forest Management Act, 2009; Padari et al., 2009). Dominant stand height, which is suggested to be a better measure of site productivity, is widely used in other countries (van Laar \& Akça, 1997; Burkhart \& Tomé, 2012) and could also be an alternative for Estonia. A primary prerequisite in using dominant height as a site index productivity measurement, instead of mean height, is that the height growth of dominant trees is not so greatly influenced by stand density (Weiskittel et al., 2009). Therefore, the use of dominant height should be a more precise way of evaluating stand growth (Burkhart \& Tomé, 2012).

In literature, different names and definitions of dominant height have been proposed (West, 2009). One of the most common definition is top height (sometimes used as a synonym for dominant height), which is defined as the average height of a fixed number of trees per unit area (stand) with the largest diameters at breast height (commonly over bark) (Elfving \& Kiviste, 1997; van Laar \& Akca, 1997; Sharma et al., 2002; West, 2009; Burkhart \& Tomé, 2012). A second definition, predominant height is defined as the average height of a fixed number of the tallest trees per unit area (stand) (West, 2009). Trees with a large diameter are often easier to measure, hence the use of the thickest trees is more practical than the use of the tallest trees (Burkhart \& Tomé, 2012).

The current study uses dominant height, which is defined by the IUFRO (International Union of Forest Research Organizations) as the average height of the 100 largest trees per hectare (dominant trees) (Tomé et al., 2019). The IUFRO's forest terminology prescription does not specify whether height or diameter should be used as the largest tree identifier. Since both identifiers are allowed, the following research defines dominant height as the average height of the 100 trees with the largest diameters at breast height per hectare, as it is more appropriate for the research. In the current study, we limited the comparison of mean and dominant height only to the main tree species on each plot. The term cohort will be used in our study as a grouping method, which combines tree species and storeys into subgroups.

The aim of the research is to evaluate whether there is a difference in the accuracy of stand height estimation, when comparing the mean height model and 
dominant height model. We hypothesize that thinning has no statistically significant effect on dominant height and therefore dominant height should be more accurate for site index productivity measurement.

\section{Material and Methods}

This study is based on a dataset of repeated measurements from the Estonian Network of Forest Research Plots (ENFRP). The ENFRP was established in 1995 and is active and maintained to this day. When the ENFRP was founded, its main purpose was to collect data for the construction of individual tree growth models in Estonia (Kiviste \& Hordo, 2002). Nowadays, the ENFRP has become even more relevant as it is an important database for the national research infrastructure (Kiviste et al., 2015).

\section{ENFRP measurements}

The ENFRP consist of circular sample plots with radiuses of $15,20,25$ or 30 meters. The size of the radius depends mainly on the density of the stand and as a rule, ENFRP plots include at least 100 first storey trees. If a sample plot is thinned between two consecutive measurements, the plot is enlarged to follow the 100-tree rule, by increasing the radius. The re-measurements are carried out at 5-year intervals. The sample plots are systematically distributed over Estonia and are mostly established in a group of three plots. According to the field measurement protocol, the stem diameter at breast height (measured at $1.3 \mathrm{~m}$ above the root collar) is recorded in two perpendicular directions for each individual tree. Damage and the cause of dead tree mortality are examined and recorded in addition (Kiviste et al., 2015).

\section{Research data}

This study is based on a dataset which was extracted from the ENFRP database on 11.03.2020. In our study, 753 sample plots were used, which were measured a total of
3,132 times (33 plots were measured once, 41 plots twice, 39 plots three times, 305 plots four times, 335 plots five times, and 5 plots six times). These sample plots included 139,125 measurements of different individual trees, which were measured a total of 412,604 times. The main tree species of the ENFRP plots in this study were Scots pine (Pinus sylvestris L.) - 347 plots, Norway spruce (Picea abies (L.) H. Karst.) - 210 plots, silver birch (Betula pendula Roth) on mineral soil or silver birch in mix with downy birch (Betula pubescens Ehrh.) on wet sites - 143 plots, European aspen (Populus tremula L.) 34 plots, common alder (Alnus glutinosa (L.) Gaertn.) - 6 plots, grey alder (Alnus incana (L.) Moench) - 6 plots, goat willow (Salix caprea L.) - 6 plots and small-leaved lime (Tilia cordata Mill.) - 1 plot. According to the forest site typology (Lõhmus, 1984), the ENFRP plots were classified into 11 forest type groups, the most frequent of which were mesotrophic, meso-eutrophic and nemoral forests (Figure 1).

\section{Relation between dominant and main tree species}

A considerable share of Estonian forests has a semi-natural status, which means that even commercially planted forests contain some trees of natural regeneration in the first storey (Lõhmus et al., 2013). Figure 2 shows that sample plots where Scots pine is the main species are mostly dominated by Scots pine trees. However, sample plots with Norway spruce and other deciduous species (European aspen, common alder, grey alder, goat willow, small-leaved lime) have a more mixed composition in the cohort of dominant trees. Thus, according to our calculation, trees of the main tree species are not always dominant trees.

\section{Mean square diameter and dominant diameter calculation}

The diameter of each individual tree is recorded at each sample plot measurement according to the ENFRP field measurement protocol. However, only $30.5 \%$ of 


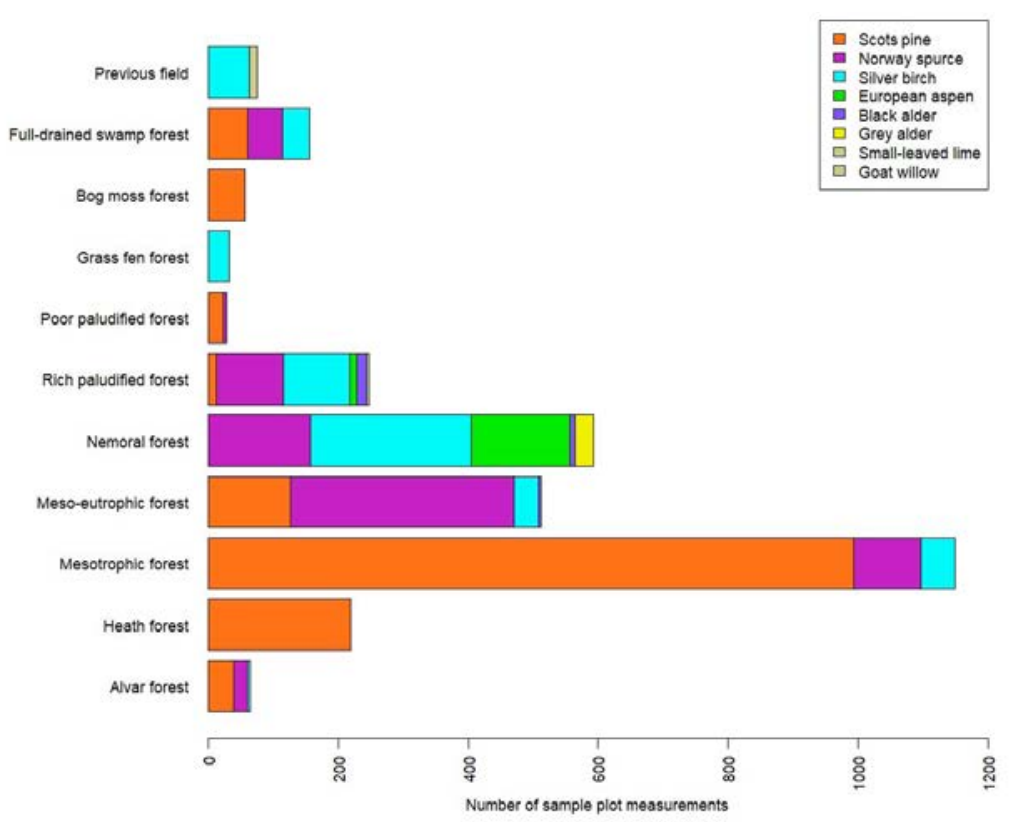

Figure 1. Distribution of the ENFRP plot measurements by forest type and main tree species.
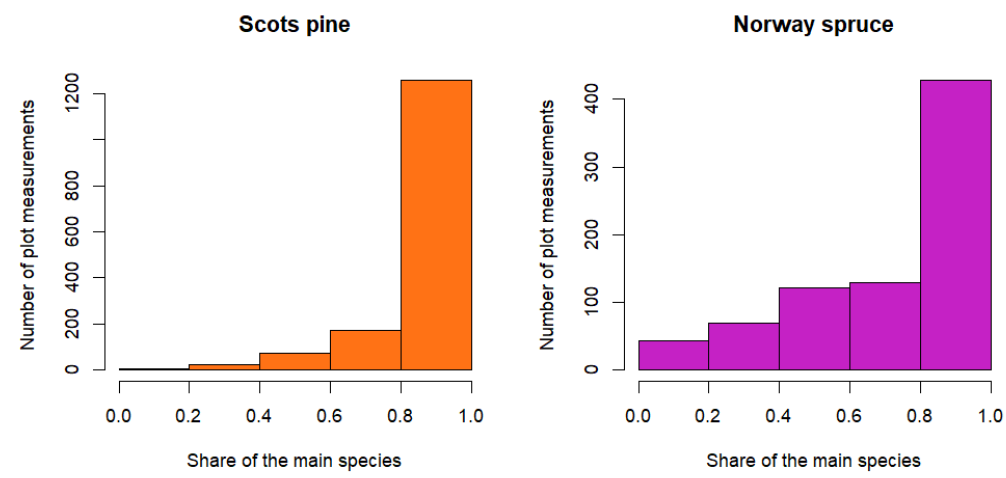

Silver birch

Other deciduous
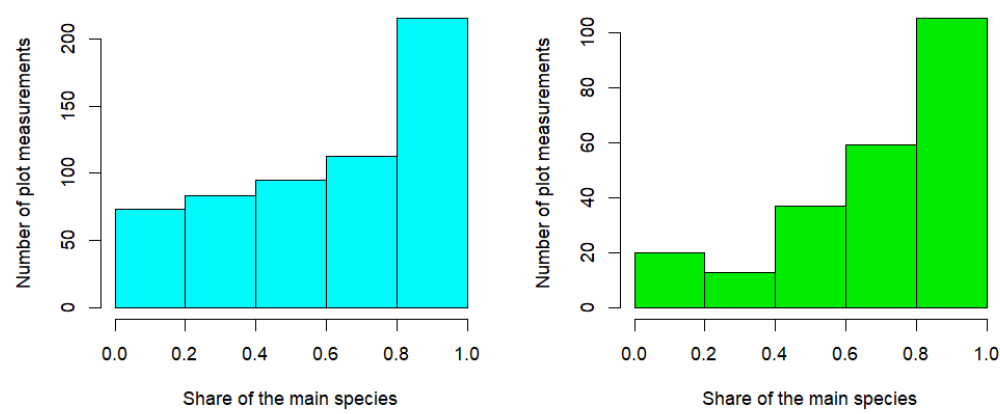

Figure 2. Distributions of the main species share in the dominant tree cohort for main species groups. 
the tree heights were recorded during the measurements, as the methodology stipulates that only a part of the tree heights is recorded during the sample plot measurements. Since a height measurement was required for each individual tree, we estimated the parameters of the height curve from height-diameter data obtained at sample plot measurement.

First, we calculated the mean square diameter (root mean square) $d_{g}$ for the main tree species of the first storey for each plot measurement. Second, we calculated the dominant diameter $\mathrm{d}_{\mathrm{g}}$ dom. However, in order to calculate the dominant diameter $\mathrm{d}_{\mathrm{g}}$ dom, we had to find a way to distinguish dominant trees from individual trees in a sample plot. We decided to calculate the number of dominant trees to be included per sample plot from the radius of the plot. For example, sample plots with a radius of 15,20 , or 25 had an area of $0.071,0.126$, or 0.196 hectares and therefore, 7,13 , or 20 trees with the largest diameter at sample plot measurement were used as dominant trees. In total, 38,960 tree measurements were treated as dominant tree measurements. The dominant diameter $\mathrm{d}_{\mathrm{g}}$ dom was calculated with the same formula (1) as the mean square diameter, but only dominant trees were used instead of all trees.

$$
d_{g}=\sqrt{\frac{\sum d_{i}^{2}}{n}}
$$

where $d_{g}$ - mean square diameter (calculated separately for each sample plot); $d_{i}$ - breast height diameter of an individual tree $(\mathrm{cm}) ; \mathrm{n}-$ number of trees in a cohort.

\section{Height curve selection}

There is a substantial number of mathematical functions (height curves), which can be used to approximate the heightdiameter relationship of trees in forest stands (eg. Padari, 1994; van Laar \& Akça, 1997; Sharma, 2009; Mehtätalo et al., 2015). In order to find the best solution for the dominant height estimation, we tested five different models which have been used for modelling the height-diameter relationship for Estonian forests in recent years. Three models $(2,3,5)$ were based on Näslund's (1937) curve and two models $(4,6)$ were based on Nilson's (2002) transformation of the Hossfeld forest growth function (Hossfeld, 1822; Peschel, 1938). In the growth model calculation, we only used one cohort at each sample plot, which is the main trees species of the first storey. Tree-specific coefficients of the growth curves are presented in Table 1.

$$
h=1.3+\left[\frac{d}{(a+b * d)}\right]^{2}
$$

where $\mathrm{h}$ - tree height (m); $\mathrm{d}$ - tree diameter (cm); a and b- model parameters estimated for each cohort using nonlinear regression (Näslund, 1937).

$$
h=1.3+\left[\frac{d}{(a+b * d)}\right]^{3}
$$

where $\mathrm{h}$ - tree height $(\mathrm{m}) ; \mathrm{d}$ - tree diameter (cm); a and b- model parameters estimated for each cohort using nonlinear regression (Näslund, 1937).

$$
h=\frac{H}{\left\{1-b *\left[1-\left(\frac{d_{g}}{d}\right)^{c_{s p}}\right]\right\}}
$$

where $\mathrm{h}$ - tree height $(\mathrm{m})$; $\mathrm{d}$ - tree diameter (cm); $\mathrm{d}_{\mathrm{g}}$ - quadratic mean diameter; $\mathrm{H}$ and $\mathrm{b}$ - model parameters (Nilson, 2002; Kiviste et al., 2003) estimated for each height-diameter cohort; $\mathrm{c}_{\mathrm{sp}}$ - tree-specific coefficient (Nilson, 2002; Kiviste et al., 2003).

$$
h=1.3+\left[\frac{d}{\left(a_{s p} * \log \left(d_{g}+1\right)+b * d\right)}\right]^{3}
$$

where $\mathrm{h}$ - tree height $(\mathrm{m})$; $\mathrm{d}$ - tree diameter $(\mathrm{cm})$; $\mathrm{d}_{\mathrm{g}}$ - quadratic mean diameter; $b$ - model parameter (Näslund, 1937) estimated for each height-diameter cohort; $a_{\text {sp }}$ - tree-specific coefficient (estimated from ENFRP data). 
Table 1. Values of species-specific coefficients for height curve models 4, 5 and 6.

\begin{tabular}{llcccc}
\hline Model & Coefficient & Scots pine & Norway spruce & Silver birch & Other deciduous \\
\hline 5 & $\mathrm{a}_{\mathrm{sp}}$ & 0.30201 & 0.44325 & 0.27936 & 0.27936 \\
6 & $\mathrm{a}_{\mathrm{sp}}$ & 0.32044 & 0.44103 & 0.39554 & 0.25803 \\
6 & $\mathrm{~b}_{\mathrm{sp}}$ & 0.00434 & 0.00643 & 0.00629 & 0.00582 \\
4,6 & $\mathrm{c}_{\mathrm{sp}}$ & 1.48076 & 1.37255 & 1.32998 & 2.04430 \\
\hline
\end{tabular}

$$
h=\left\{\frac{\mathrm{H}}{\left\{1-\left(a_{s p}+b_{s p} * d_{g}\right) *\left[1-\left(\frac{d_{g}}{\mathrm{~d}}\right)^{c_{s p}}\right]\right\}}\right\}
$$

where $\mathrm{h}$ - tree height $(\mathrm{m}) ; \mathrm{d}$ - tree diameter $(\mathrm{cm}) ; \mathrm{d}_{\mathrm{g}}$ - quadratic mean diameter; $\mathrm{H}$ - model parameter (Nilson, 2002; Kiviste et al., 2003) estimated for each height-diameter cohort; $\mathrm{c}_{\mathrm{sp}}$ - tree-specific coefficient (Nilson, 2002; Kiviste et al., 2003); $\mathrm{a}_{\mathrm{sp}}$ and $\mathrm{b}_{\mathrm{sp}}$ - tree-specific coefficients (ForMIS 2020, model 206, estimated by A. Sims from ENFRP data).

The calculations with the set of height curve test data were performed as follows:

1. We joined consecutive tree measurements pairwise, which were made at five-year intervals. We calculated the annual increase in diameter and height (id and ih) for each period. The annual increment was calculated only when the diameter and height of the tree were recorded in the database at both the beginning and the end of the period. Only the main tree species of the first storey was included in the calculations.

2. A mixed effect model with a random intercept (Pinheiro \& Bates, 2000) $i d_{k j}=\beta_{1}+\beta_{2} \cdot d_{k j}+\beta_{3} \cdot r d_{k j}+b_{k}+\varepsilon_{k j}$ was created where $\mathrm{id}_{\mathrm{kj}}$ denotes diameter annual increment of tree j on plot k. Part $\beta_{1}+\beta_{2} \cdot d_{k j}+\beta_{3} \cdot r d_{k j}$ is the fixed part and part $b_{k}+\varepsilon_{k j}$ is the random part of the model. The fixed variables $d_{k j}$ and $r d_{k j}$ denote diameter and relative diameter (ratio of tree diameter and sample plot dominant diameter) of tree $\mathrm{j}$ on plot $\mathrm{k}$.
The random effect of plot $b_{k}$ and tree $\varepsilon_{k j}$ is assumed to be independent and have normal distribution $b_{k} \sim N\left(0, \sigma_{b}^{2}\right)$ and $\varepsilon_{j k}$ $\sim N\left(0, \sigma^{2}\right)$. Values $\beta_{1^{\prime}}, \beta_{2^{\prime}}, \beta_{3^{\prime}}, \sigma_{\mathrm{b}}^{2}$ and $\sigma^{2}$ are model parameters estimated with $\mathrm{R}$ package lme4 function lmer. For excluding diameter increment outliers, threshold values were determined as 0.025 and 0.975 quantiles of the id model residuals (Figure 3). A similar approach was applied for excluding height increment outliers. It was done in order to avoid human mistakes during forest measurements and data inputs.

3. After excluding id and ih outliers, plot measurements with at least 16 main species height-diameter measurements were included in the height curve test dataset. The test dataset consisted of 64,281 height-diameter records for 6,581 dominant trees at 1,798 plot measurements.

In order to characterize the suitability of the height growth models (2-6), we calculated estimates of their parameters for each height-diameter cohort using the test dataset and predicted height for each main species dominant tree with all five models. Table 2 presents the calculated statistics for $h_{\text {measured }}$ and $h_{\text {predicted }}$ which characterize the systematic and random error of the models. It also shows t-test results and the decrease in the height curve. The specifications of Table 2 are given in Table 3 .

We calculated dominant heights $\mathrm{h}_{\mathrm{g}}$ dom with five different height curve models (2-6) at dominant diameter $\mathrm{d}_{\mathrm{g}}$ dom for each cohort. In addition, we calculated the arithmetic mean height of the main 


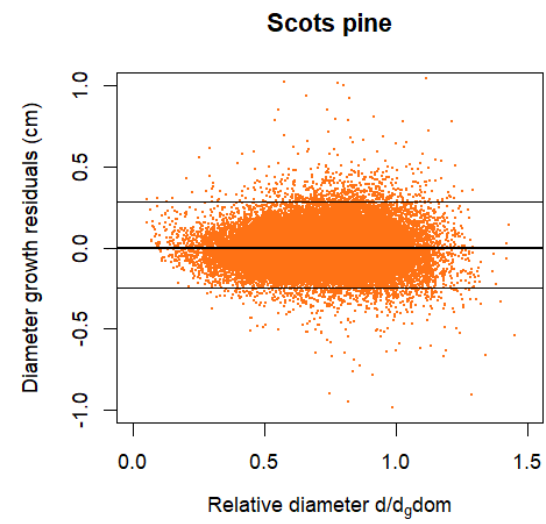

Silver birch

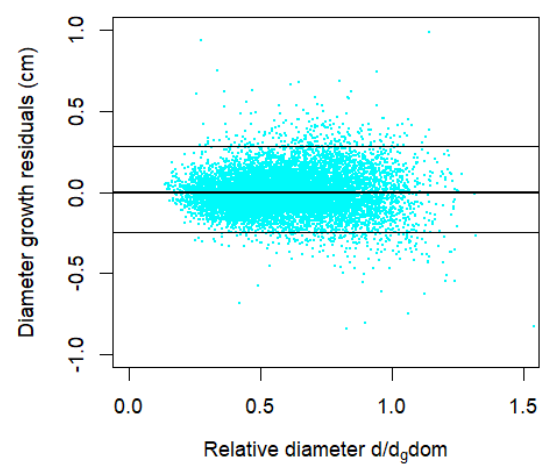

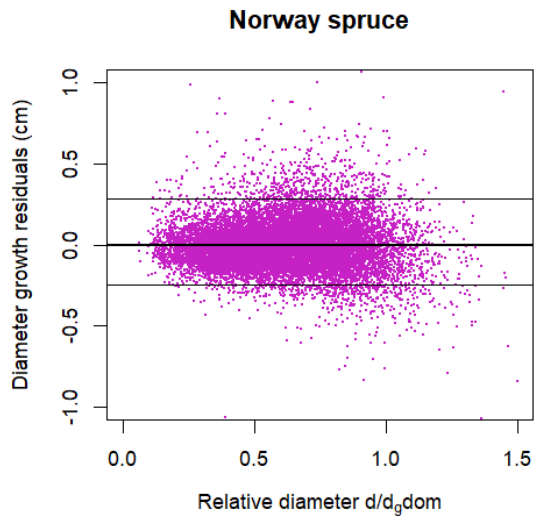

Other deciduous

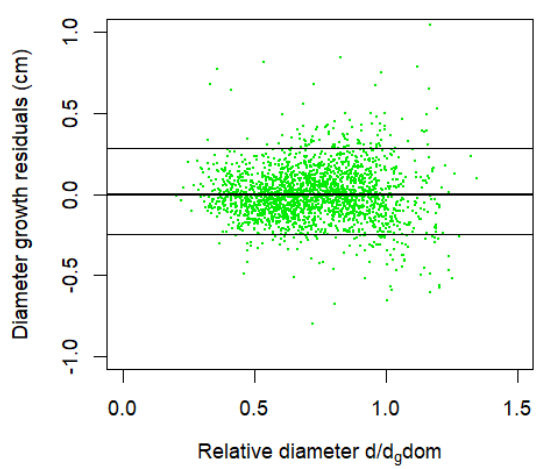

Figure 3. Distribution of residuals and threshold values for excluding diameter annual increment (id) outliers on a scatterplot of id mixed model residuals and relative diameter ( $d / d_{g}$ dom).

species dominant trees (if possible) for each cohort for comparison. Figure 4 shows the difference between the estimated dominant height $h_{g}$ dom and the empirical arithmetic mean height of the 100 thickest trees per hectare. The difference boxplots of all five candidate height curve models are presented in the same figure.

Model 4 (Nilson, 2002) fits our dominant height test data most accurately, but because it contains two parameters and the elevation curve may be descending for certain plots, it was not the best choice. We chose the single-parameter height curve model (6) instead. According to Table 2, model (6) had a slightly larger height prediction error $($ sde $=1.45 \mathrm{~m}$ ) compared to model (4), which had an estimation error of $1.34 \mathrm{~m}$. However, model (6) maintained the basic height curve requirement (non-decreasing) for all height-diameter cohorts of the main species in the test dataset.

\section{Mean height and dominant height relationship}

We applied the one-parameter height curve function (6) on height-diameter cohorts of the main tree species for all the ENFRP plot measurements. Due to possible outliers in height-diameter measurement data, we estimated function (6) parameter $\mathrm{H}$ with a robust approach as the median estimate. Using the model (6) with the median-estimated parameter $\mathrm{H}$, we calculated the mean height $h_{g}$ as the model prediction at the mean square diameter $\mathrm{d}_{\mathrm{g}}$ and the dominant height $\mathrm{h}_{\mathrm{g}}$ dom as the model prediction for the dominant 
Table 2. Fit statistics of the height curve models (2-6) for dominant trees based on experimental data. ( $n$ - number of trees; me - mean residual; sde - mean square residual; $p$-value $p$-value of $t$-test, desc-number cohorts with a descending height curve).

\begin{tabular}{lccccc}
\hline Statistic & Scots pine & Norway spruce & Silver Birch & $\begin{array}{c}\text { Other } \\
\text { deciduous }\end{array}$ & All species \\
\hline $\mathrm{n}$ & 5165 & 914 & 426 & 76 & 6581 \\
\hline Model (2) me & -0.08 & -0.17 & -0.18 & -0.23 & -0.10 \\
Model (2) sde & 1.37 & 1.18 & 1.38 & 1.41 & 1.35 \\
Model (2) p-value & $<0.001$ & $<0.001$ & 0.008 & 0.165 & $<0.001$ \\
Model (2) desc & 5 & 0 & 1 & 0 & 6 \\
\hline Model (3) me & -0.07 & -0.13 & -0.15 & -0.21 & -0.09 \\
Model (3) sde & 1.37 & 1.18 & 1.38 & 1.40 & 1.35 \\
Model (3) p-value & $<0.001$ & 0.001 & 0.025 & 0.188 & $<0.001$ \\
Model (3) desc & 5 & 0 & 1 & 0 & 6 \\
\hline Model (4) me & -0.01 & -0.08 & -0.11 & 0.01 & -0.03 \\
Model (4) sde & 1.37 & 1.17 & 1.37 & 1.35 & 1.34 \\
Model (4) p-value & 0.602 & 0.044 & 0.113 & 0.937 & 0.127 \\
Model (4) desc & 5 & 0 & 1 & 0 & 6 \\
\hline Model (5) me & -0.09 & -0.61 & -0.14 & -0.44 & -0.17 \\
Model (5) sde & 1.47 & 1.45 & 1.51 & 1.49 & 1.47 \\
Model (5) p-value & $<0.001$ & $<0.001$ & 0,060 & 0,009 & $<0.001$ \\
\hline Model (6) me & -0.03 & -0.05 & -0.23 & 0.02 & -0.04 \\
Model (6) sde & 1.47 & 1.32 & 1.52 & 1.37 & 1.45 \\
Model (6) p-value & 0.142 & 0.301 & 0.002 & 0.896 & 0.013 \\
\hline
\end{tabular}

Table 3. Height curve statistics specifications for Table 2.

Height curve statistics

$n$ - number on dominant trees;

$m e-$ arithmetic mean residual $h_{\text {measured }}-h_{\text {predicted }}$ (systematic error);

sde-quadratic mean residual $h_{\text {measured }}-h_{\text {predicted }}$ (random error);

$p$-value - $t$-test for hypothesis that mean residual is different from zero;

desc- despite excluding outliers and a moderate number of observations $(n \geq 16)$ in each cohort, the height curve was descending (parameter $a<0$ for models 2 and 3 , parameter $b<0$ for model 4 ) in the case of some cohorts. 
Scots pine

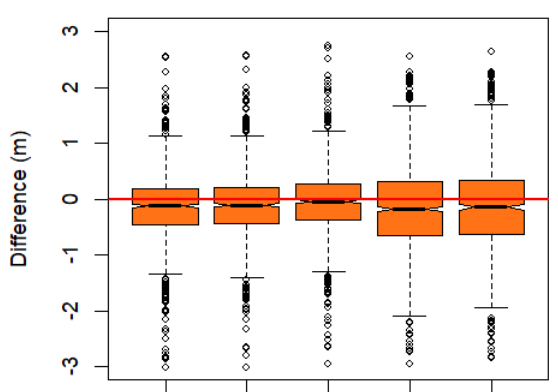

$\begin{array}{llll}(2) \quad(3) \quad(4) \quad(5) \quad(6) & 0\end{array}$

Height curve model

Silver birch

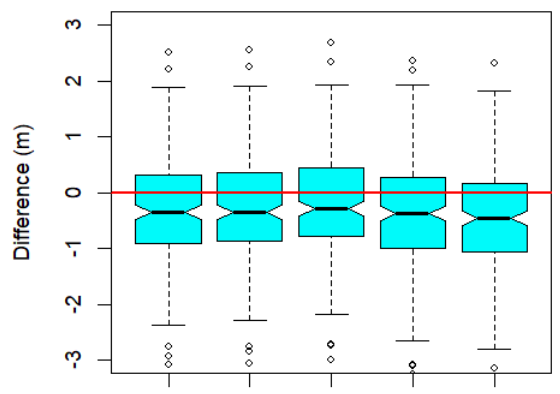

(2)
(3)

(4)

(5)

(6)

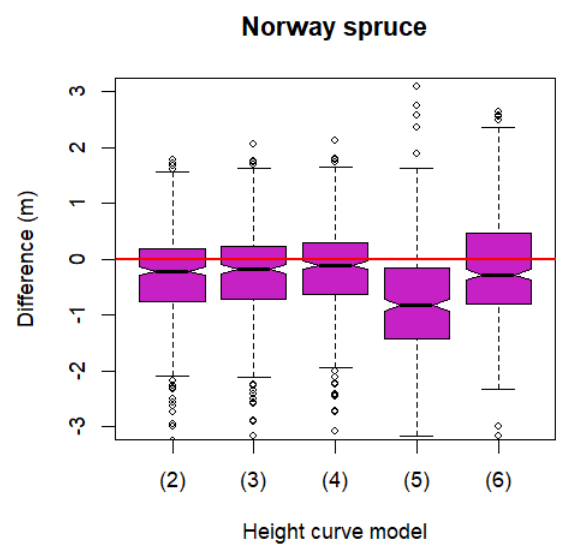

Other deciduous

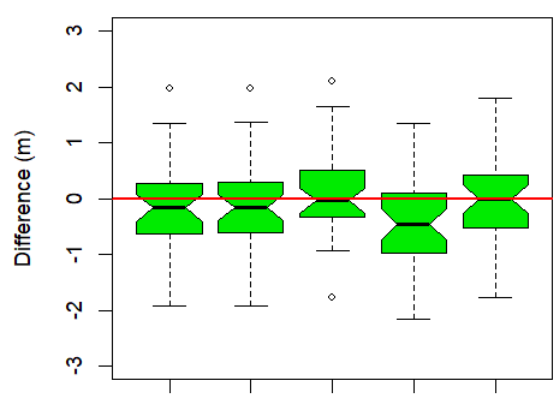

(2)
(3)

(4)

(5)

(6)

Height curve model

Figure 4. The difference between the estimated dominant height $\mathrm{h}_{\mathrm{g}}$ dom and the empirical arithmetic mean height of the 100 thickest trees per hectare.

diameter $\mathrm{d}_{\mathrm{g}}$ dom of the main tree species of each plot measurement. We studied the relationship between the dominant height and other stand variables with the multiple regression method.

Thinning and mortality effects on mean and dominant stand height

A dataset of pairwise consecutive tree measurements $(317,588$ measurement pairs) were compiled in order to calculate the basal area change due to thinning and mortality. The aggregated thinning and mortality data were merged with other stand (plot) variables (age, mean square diameter, mean and dominant height etc.) into pairwise consecutive plot data. The purpose of the new dataset was to investigate whether thinning and mortality have an effect on the mean and dominant height.

Figure 5 shows the share of the thinned basal area in relation to the basal area of the main species between two consecutive plot measurements depending on stand age. We introduced a binary variable "TH", referring to "thinned", when at least $5 \%$ of the basal area of the main tree species was cut at 5-year intervals and "NTH" (not thinned) otherwise. There were 364 measurement intervals with thinning above the 5\% threshold percentage (thinned) and 1,959 measurement intervals without thinning or below the $5 \%$ threshold (not thinned). The effect of thinning on 

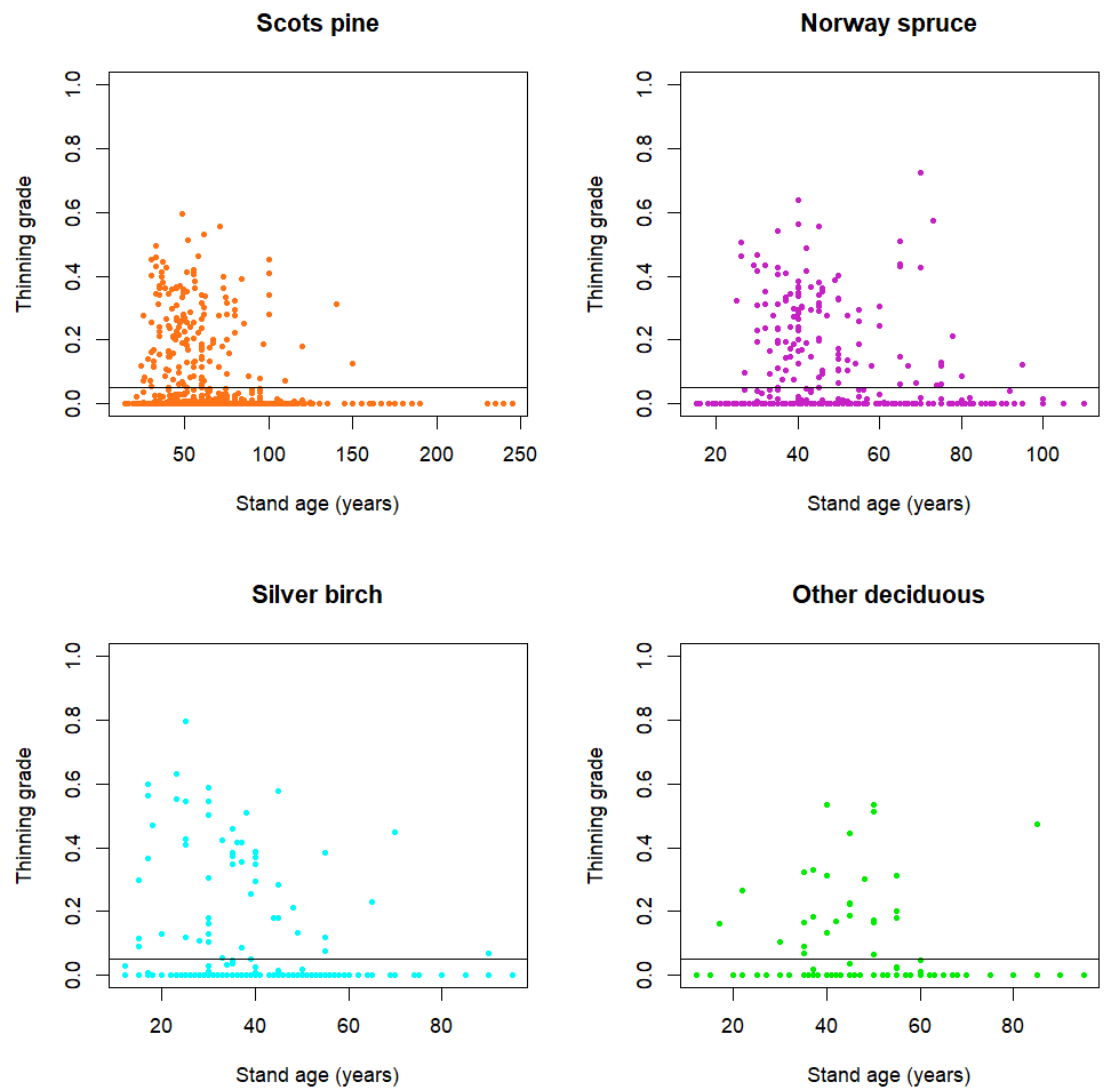

Figure 5. Share of the thinned basal area in the basal area of the main species between two consecutive plot measurements depending on stand age. The solid horizontal line shows a $5 \%$ threshold value for thinning.

changes in the mean height and dominant height during the measurement interval was studied by comparing means with confidence intervals.

In order to study the effect of mortality on mean and dominant height, we introduced a continuous variable, which expresses the share of the dead tree basal area in relation to the basal area of the main species in two consecutive plot measurements depending on stand age (Figure 6).

\section{Evaluation of height growth models on mean height and dominant height growth predictions}

In order to study the accuracy of mean and dominant height as stand height in forest growth predictions, two models were tested and compared. The Estonian difference model (Kiviste, 1997) was used to calculate the predicted mean height growth. The model is based on the 1984-1993 Estonian State Forests Inventory data (Kiviste, 1997). Mean height growth was predicted using the following equations:

$$
\begin{gathered}
H_{2}=\frac{\left(H_{1}+Y+Z\right)}{\left(\frac{2+4 *\left(X * A_{2}{ }^{-1.58}\right)}{H_{1}-X+Z}\right)} \\
X=(8319)-493 * \log (O H+1)+1355 * K \\
Y=\frac{X}{50^{1.58}} \\
Z=\sqrt{\left(H_{1}-Y\right)^{2}+4 * X * \frac{H_{1}}{A_{1}^{1.58}}}
\end{gathered}
$$


Scots pine

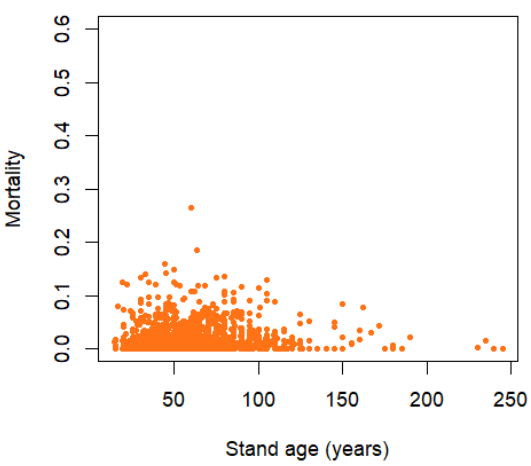

Silver birch

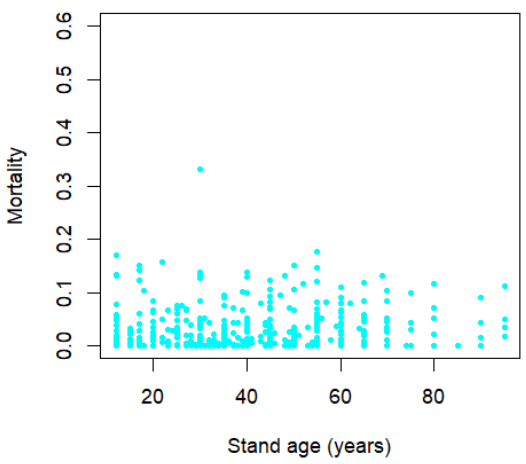

Norway spruce

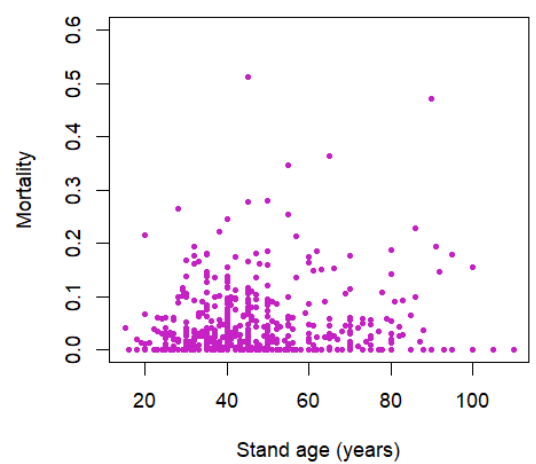

Other deciduous

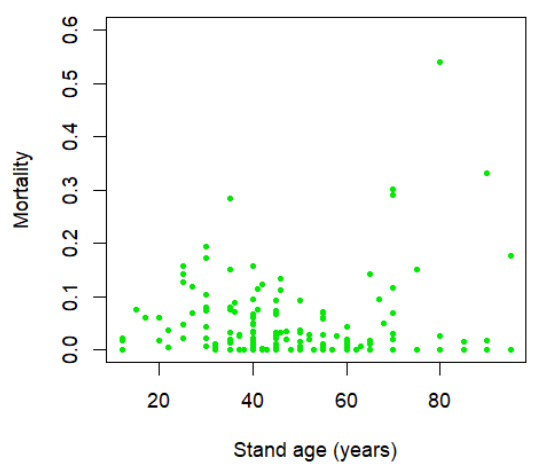

Figure 6. The share of the dead tree basal area in the basal area of the main species between two consecutive plot measurements depending on stand age.

where $\mathrm{H}_{2}$ - estimated mean height growth (m); $\mathrm{H}_{1}-$ mean height at the beginning of the period (m); $A_{1}$ - stand age at the beginning of the period (year); $A_{2}-$ age of stand at the end of the period (year); $\mathrm{OH}$ - thickness of the organic layer of the soil $(\mathrm{cm}) ; \mathrm{K}-$ stand formation (uncultivated, $\mathrm{K}=0$, or cultivated, $\mathrm{K}=1$ ); $\mathrm{X}, \mathrm{Y}, \mathrm{Z}$ - auxiliary variables.

As a second model, the Swedish Scots pine growth model (Elfving \& Kiviste, 1997) was used to predict the dominant height. The model is based on repeated measurements of the permanent plots measured by the Swedish University of Agriculture and uses dominant height in its calculation. Dominant height growth was predicted using the following equations:

$$
H_{2}=\frac{\left(H_{1}+r+23.8\right)}{\left[2+\frac{\frac{29582}{A_{2}{ }^{1.7829}}}{H_{1}+r-23.80}\right]}
$$

$r=\sqrt{\left(H_{1}-23.80\right)^{2}+29582 * \frac{H_{1}}{A_{1}^{1.7829}}}$

where $\mathrm{H}_{2}$ - dominant height at the end of the period (m); $\mathrm{H}_{1}$ - dominant height at the beginning of the period (m); $\mathrm{A}_{1}$ - stand age at the beginning of the period (year); $\mathrm{A}_{2}-$ age of stand at end of the period (year); $r$ - auxiliary variable.

The results of the mean and dominant height models were compared with the 

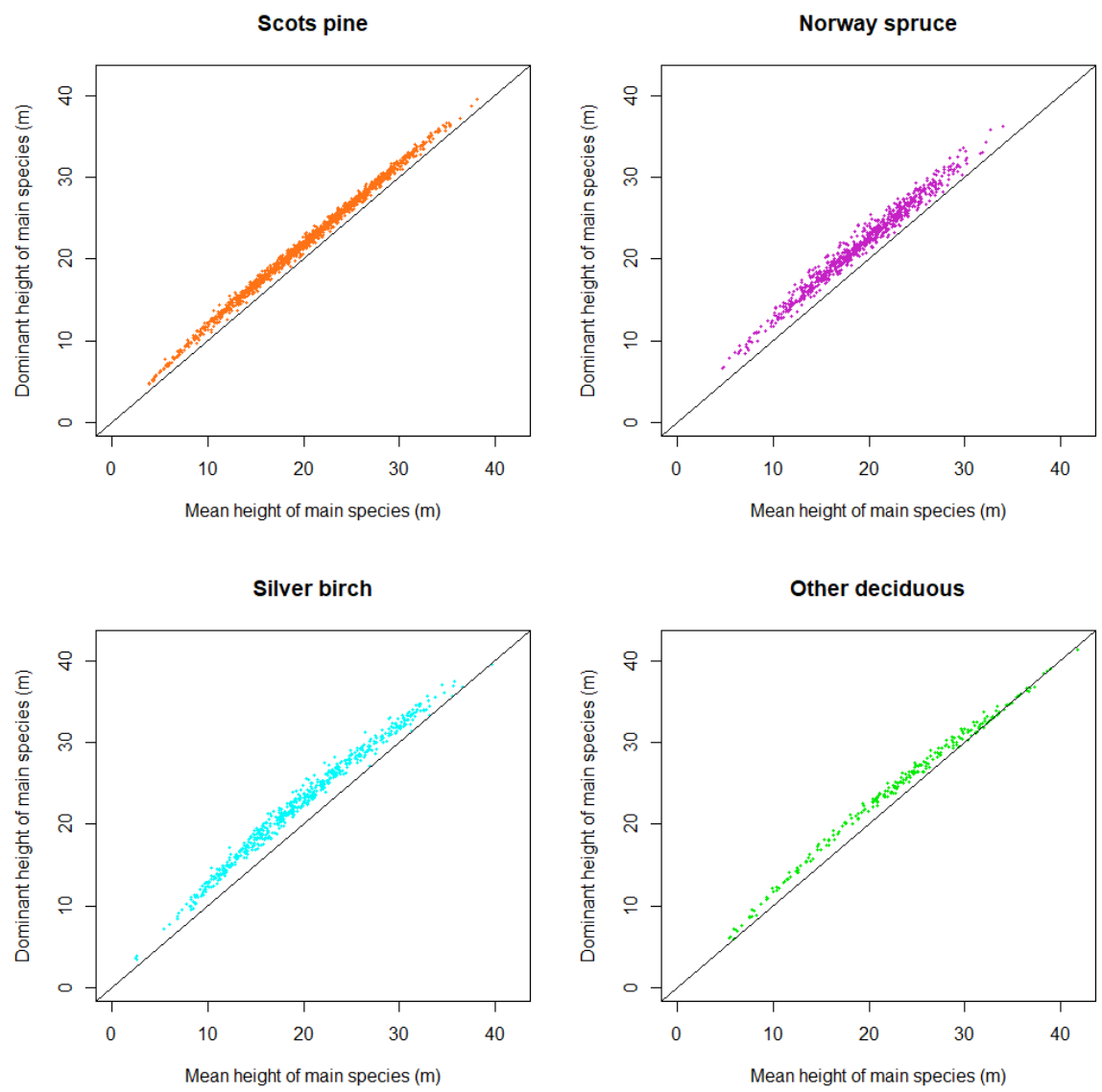

Figure 7. Scatterplots of the mean height $h_{g}$ and the dominant height $h_{g}$ dom of cohorts by tree species.

values of the evaluated mean and dominant height in order to validate the accuracy of model estimates. All the calculations were made in $\mathrm{R}$ version 3.6.3.

\section{Results}

\section{Relationship between dominant height and mean height}

The difference between the mean height $\mathrm{h}_{\mathrm{g}}$ and the dominant height $\mathrm{h}_{\mathrm{g}}$ dom is presented in Figure 7. Scatterplots only include the main tree species of each ENFRP sample plot. The results show a nonlinear pattern of the relationship between mean and dominant height, which indicates the possible influence of several stand variables (age, mean square diameter, mean and dominant height etc.).

After trying several variable combinations, we developed a regression model (9). The model can be used to calculate the dominant height of the main tree species with stand attributes (mean height, quadratic mean diameter and density). Species-specific coefficients of the model are presented in Table 4.

$$
\begin{gathered}
h_{g} \text { dom }=a_{0}+1.1165 * h_{g}+ \\
+a_{1} * d_{g}+\frac{a_{2}}{\sqrt{(N)}}
\end{gathered}
$$

where $\mathrm{h}_{\mathrm{g}}$ dom - dominant height (m) with 
height curve at dominant diameter $\mathrm{d}_{\mathrm{g}}$ dom $(\mathrm{cm}) ; \mathrm{h}_{\mathrm{g}}$ - mean height $(\mathrm{m})$ of the main tree species with height curve $d_{g}(\mathrm{~cm})$; $\mathrm{d}_{\mathrm{g}}$ - mean square diameter $(\mathrm{cm})$ of the main tree species, $\mathrm{N}$ - number of upper-layer trees per ha, $a_{0}, a_{1}, a_{2}$ - species-specific coefficients (Table 4).

The residual standard deviation of the regression equation (9) was $0.466 \mathrm{~m}$ and the coefficient of determination $R^{2}=0.995$. All coefficients were highly significant (p-value $<0.0001)$.

Table 4. Species-specific coefficients for regression model (9).

\begin{tabular}{lcccc}
\hline $\begin{array}{l}\text { Coeffi- } \\
\text { cient }\end{array}$ & $\begin{array}{c}\text { Scots } \\
\text { pine }\end{array}$ & $\begin{array}{c}\text { Norway } \\
\text { spruce }\end{array}$ & $\begin{array}{c}\text { Silver } \\
\text { birch }\end{array}$ & $\begin{array}{c}\text { Other } \\
\text { deciduous }\end{array}$ \\
\hline $\mathrm{a}_{0}$ & 2.0494 & 3.3661 & 3.0474 & 1.7910 \\
$\mathrm{a}_{1}$ & -0.0964 & -0.1231 & -0.0824 & -0.1108 \\
$\mathrm{a}_{2}$ & -15.686 & -14.070 & -34.854 & -15.215 \\
\hline
\end{tabular}

\section{Effect of thinning on mean height and dominant height}

The difference in the thinning effect on the 5 -year increment of mean height and dominant height is shown in Figure 8, where the average change in mean height and dominant height with $95 \%$ confidence intervals is presented. The dataset containing 5-year measurements was split by thinning (" $\mathrm{TH}^{\prime}$ or "NTH") and by tree species. Confidence intervals for mean height and dominant height were calculated on the same dataset. Figure 8 shows that for commercially important tree species (Scots pine, Norway spruce, silver birch), the change in the average mean height is significantly greater in the case of thinning when compared to undisturbed stand development. Whereas the change in the average dominant height in the case of thinning compared to undisturbed development was not significant. This is evidence of the Estonian forest management practice of applying thinning from below. The other deciduous tree species include species that are cut out at a thinning event, as economically beneficial species (Scots pine, Norway spruce, and Silver birch) are preferred. Figure 9 shows the increase in dominant height between the beginning and the end of a five-year period, however, effect of thinning is not apparent. Figure 10 shows height growth model errors for the mean height model (7) and the dominant height model (8). The figure shows that both models underestimate the height growth on forest permanent plots. If thinning occurs between two measurements then mean height growth model error is higher than dominant height growth model error. However, when thinning do not occur between the measurements then obvious difference between the forest growth model errors is not evident.

\section{Discussion}

The dominant height can be calculated in different ways (West, 2009). We calculated dominant height as the model prediction at the dominant diameter of each plot measurement. The advantage of our approach is that the dominant height can be calculated even if there are no dominant trees of the main tree species. The disadvantage of this approach is that we are extending the height curve of the main tree species to all tree species. This might cause systematic errors as the height curve is calculated for main tree species trees and not for all trees.

As an interesting additional result, we developed a regression model that can be used to estimate the dominant height of the main tree species by stand attributes (mean height, quadratic mean diameter and density) with a residual standard deviation of 0.466 . The outcome is significant as the prediction precision was more than twice as accurate when compared to the empirical dominant height prediction of model (6), which had a residual standard deviation of $1.45 \mathrm{~m}$. This means that the dominant height could be calculated easily from stand attributes as a new stand variable without additional measurement work. 

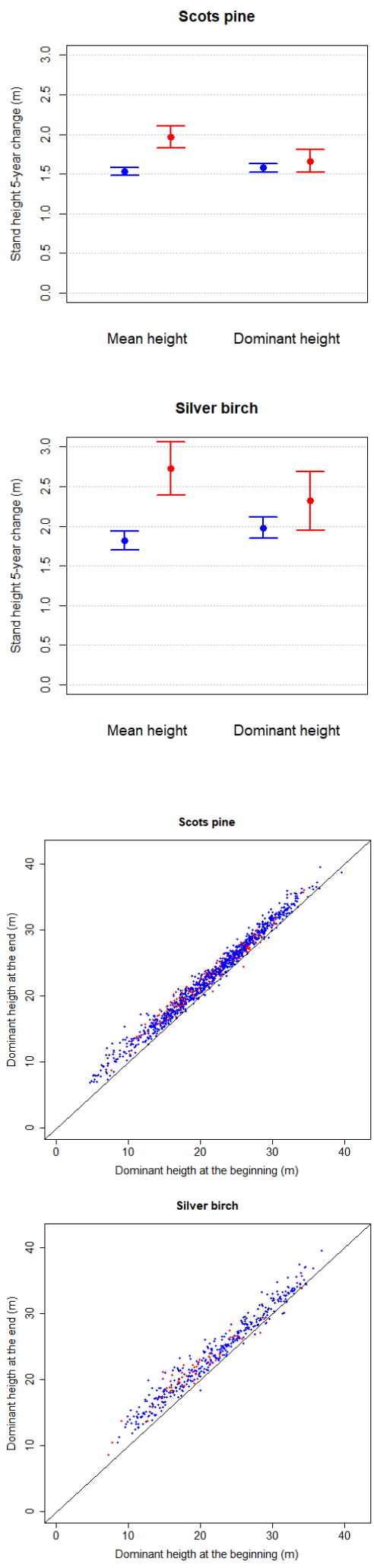
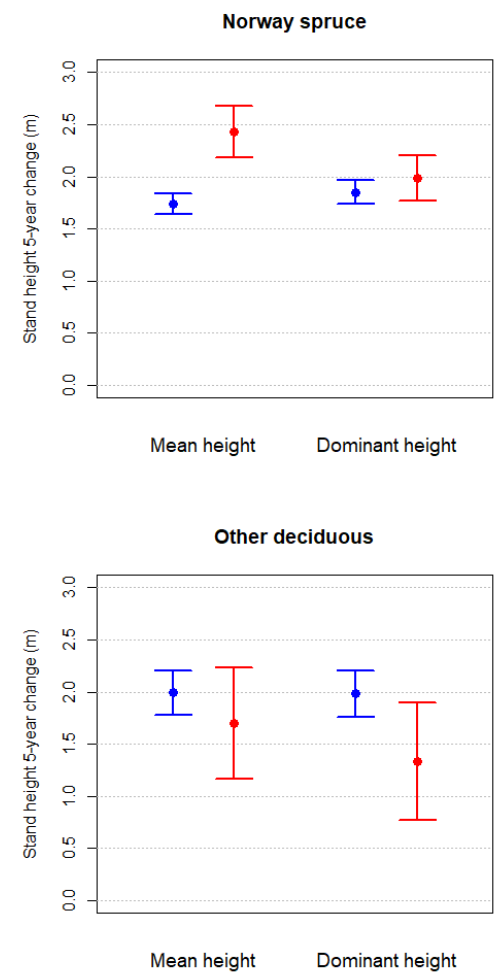

Figure 8.

The average change in the mean height and dominant height with a $95 \%$ confidence interval. The sample plots were measured at a 5-year interval. Red dots represent thinned sample plots and blue dots represent unthinned sample plots.
Figure 9.

The difference in the dominant height between the beginning and the end of the fiveyear period. Red dots represent thinned sample plots and blue dots represent unthinned sample plots.

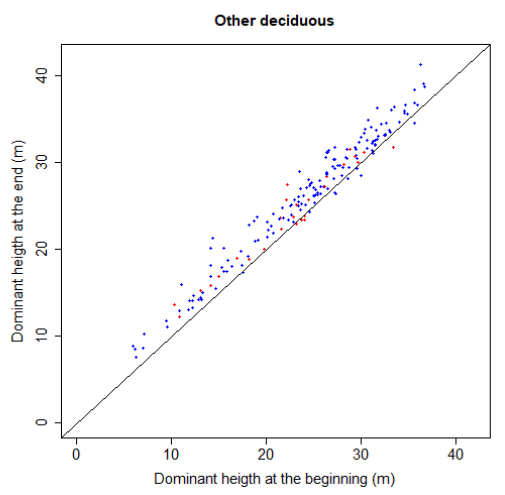



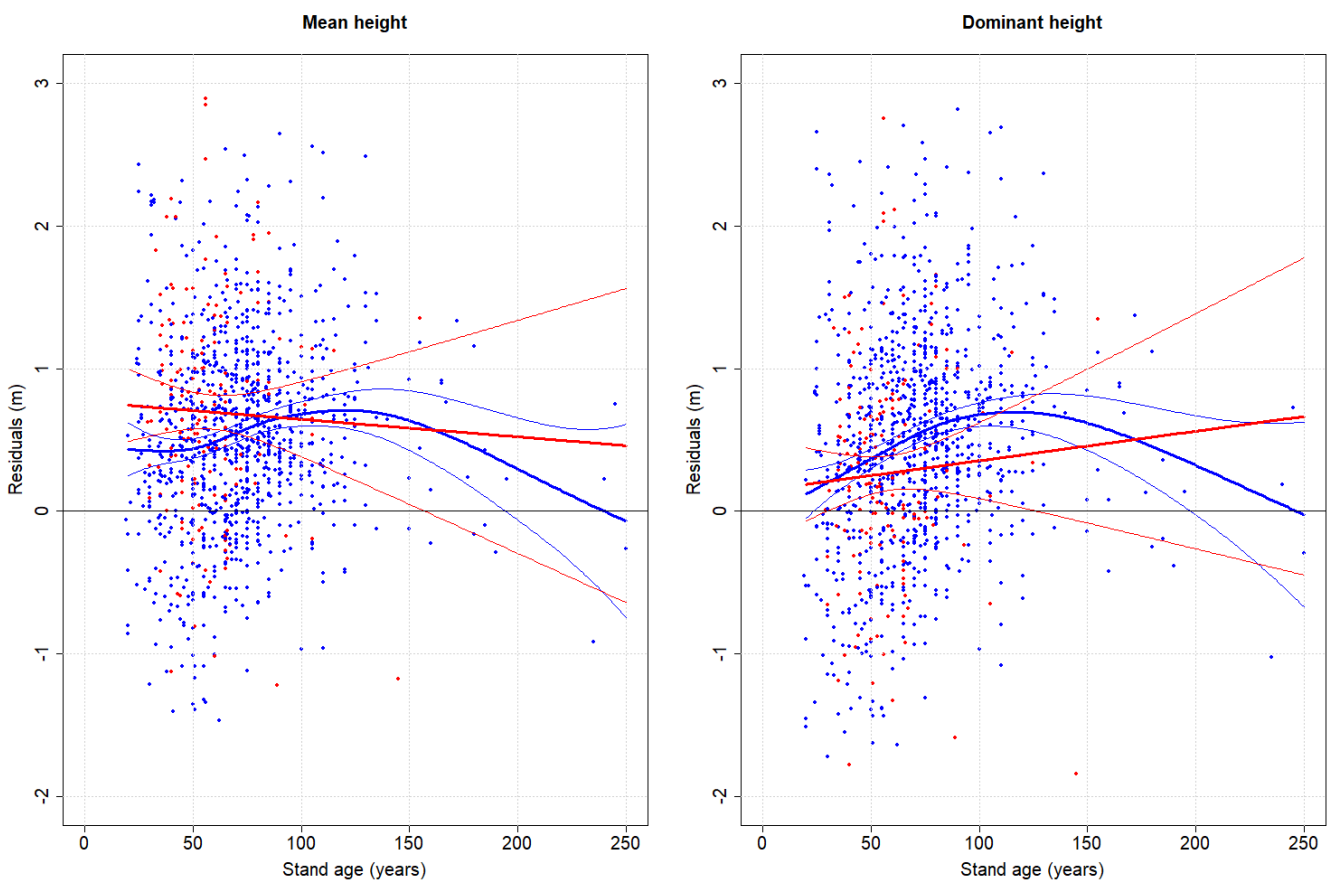

Figure 10. Growth error of the mean height model (7) and the dominant height model (8). Red dots represent thinned sample plots and blue dots represent unthinned sample plots.

Both height growth models $(7,8)$ estimated the height growth to be greater when compared to the subsequent stand plot measurement data (Figure 10). The dominant height model estimated the height growth more accurately when thinning took place between the measurements. The results suggest that the dominant height could be used in Estonia to get more accurate forest growth estimation results as a large portion of Estonian forests are managed. Our study corresponds with other studies (Amaro et al., 2003, Medeiros et al., 2017, del Río et al., 2017), which have also found that thinning has no statistically significant effect on accuracy of forest growth predicting, when dominant height is used as stand height. However, as our results are based on sample plots and not on managed forest stands, further research is advised.

Information on the thinning effect is essential for a more accurate forest growth model and provides insight into forest management (West, 2009). From an economic point of view, the main purpose of quantifying the thinning response is to determine the range of stocking density that maximizes the growth potential of timber. It is also essential to find the minimum stock necessary to obtain the largest individual tree size without reducing the volume of the stand (Skovsgaard, 2008).

In addition to artificial thinning, natural thinning occurs and should be considered while interpreting the results. Stand density and site conditions have a significant effect on the number of dead and dying trees (Zhang et al., 2008). Tree mortality is one of the most important factors in understanding forest dynamics (Sims et al., 2014). Research on Estonian forests has found that individual tree death occurs mainly due to growth-dependent reasons (45\%), while fungi (23\%) and wind damage (16\%) play also an essential part in tree mortality (Laarmann et al., 2009). The accuracy of 
the forest growth model largely depends on the precision of the tree survival prediction (Sims et al., 2009). For an accurate forest growth model, it is important to understand all the processes that may affect forest growth, such as regeneration, growth, mortality, forest dynamics, and natural and artificial thinning.

\section{Conclusion}

Based on the results of this study, we can conclude that using the mean height instead of the dominant height would help with accuracy of forest growth predicting when thinning takes place between measurements.

If there was no thinning between subsequent measurements, the accuracy of the predictions of the dominant height forest growth model was approximately the same as that of the mean height growth model. Dominant height can be calculated using regression equation from other stand attributes (mean height, quadratic mean diameter and density).

Acknowledgements. Data collection was supported by the Estonian Environmental Investment Centre. We thank numerous colleagues, students, fieldwork staff and researchers for their work on the Estonian Network of Forest Research Plots. We also thank the anonymous reviewers who contributed significantly to the manuscript.

\section{References}

Allen, R.B. 1993. A Permanent Plot Method for Monitoring Changes in Indigenous Forests: A Field Manual. Christchurch, Manaaki Whenua - Landcare Research. 26 pp.

Amaro, A., Reed, D., Soares, P. 2003. Modelling Forest Systems. Cambridge, CABI Publishing Series. 401 pp.

Burkhart, H., Tomé, M. 2012. Modeling Forest Trees and Stands. Dordrecht, Springer. 457 pp. del Río, M., Bravo-Oviedo, A., Pretzsch, H., Löf, M., Ruiz-Peinado, R. 2017. A review of thinning effects on Scots pine stands: From growth and yield to new challenges under global change. - Forest Systems, 26(2), eR03S. https://doi.org/10.5424/fs/2017262-11325.

Elfving, B., Kiviste, A. 1997. Construction of site index equations for Pinus sylvestris L. using permanent plot data in Sweden. - Forest Ecology and Management, 98, 125-134.

Forest Management Act. 2009. Forest Management Act. (Metsa korraldamise juhend). - Riigi Teataja, RTL 2009, 9, 104. (In Estonian).

ForMIS. 2020. Forest modeling information system. Estonian University of Life Sciences. [WWW document] - URL https://formis.emu.ee/ formod/index.php?do=singmodel\&id=206. [Accessed March 11 2020].

Gadow, K., Hui, G. 1999. Modeling Forest Development. Dordrecht, Springer. 213 pp.

Hossfeld, J.W. 1822. Math for foresters. (Mathematik für Forstmänner, Ökonomen und Kameralisten). Gotha, Thüringen. 472 pp. (In German).

Kim, M., Lee, W.-K., Kim, Y.-S., Lim, C.-H., Song, C., Park, T., Son, Y., Son, Y.-M. 2016. Impact of thinning intensity on the diameter and height growth of Larix kaempferi stands in central Korea. - Forest Science and Technology, 12, 77-87. https://doi.org/10.1080/21580103.201 5.1075435 .

Kiviste, A. 1997. An algebraic difference model for the forest growth simulation in Estonia. (Eesti riigimetsa puistute kõrguse, diameetri ja tagavara vanuseridade diferentsmudel 1984.1993. a. metsakorralduse takseerkirjelduste andmeil). - EPMÜ teadustööde kogumik, 189, 63-75. (In Estonian).

Kiviste, A., Hordo M. 2002. Network of permanent forest growth plots in Estonia. - Forestry Studies / Metsanduslikud Uurimused, 37, 43-58.

Kiviste, A., Hordo, M., Kangur, A., Kardakov, A., Laarmann, D., Lilleleht, A., Metslaid, S., Sims, A., Korjus, H. 2015. Monitoring and modeling of forest ecosystems: the Estonian Network of Forest Research Plots. - Forestry Studies / Metsanduslikud Uurimused, 62, 26-38.

Kiviste, A., Nilson, A., Hordo, M., Merenäkk, M. 2003. Diameter distribution models and height-diameter equations for Estonian forests. - Amaro, A., Reed, D., Soares, P. (eds.). Modelling Forest Systems. Cambridge, CABI Publishing Series, 169-179.

Laarmann, D., Korjus, H., Sims, A., Stanturf, J.A., Kiviste, A., Köster, K. 2009. Analysis of forest naturalness and tree mortality patterns in Estonia. - Forest Ecology and Management, 258, S187-S195. 
Lorey, T. 1878. The average stock height. (Die mittlere Bestandeshöhe.) Allgemeine Forst und Jagdzeitung, 54, 149-155.

Lõhmus, E. 1984. Estonian Forest Site Types. (Eesti metsakasvukohatüübid). Tallinn, Eesti NSV Agrotööstuskoondise Info-ja juurutusvalitsus. 88 pp. (In Estonian).

Lõhmus, A., Kraut, A., Rosenvald, R. 2013. Dead wood in clearcuts of semi-natural forests in Estonia: site-type variation, degradation, and the influences of tree retention and slash harvest. - European Journal of Forest Research, 132, 335-349.

Medeiros, R.A., de Paiva, H.N., Soares, A.A.V., da Cruz, J.P., Leite, H.G. 2017. Thinning from below: effects on height of dominant trees and diameter distribution in Eucalyptus stands. Journal of Tropical Forest Science, 29, 238-247.

Mehtätalo, L., de-Miguel, S., Gregoire, T.G. 2015. Modeling height-diameter curves for prediction. - Canadian Journal of Forest Research, 45, 826-837.

Mäkinen, H., Isomäki, A. 2004. Thinning intensity and long-term changes in increment and stem form of Scots pine trees. - Forest Ecology and Management, 203, 21-34.

Nilson, A. 2002. Some fragments of stand growth and structure models. - Forestry Studies / Metsanduslikud Uurimused, 37, 9-20.

Näslund, M. 1937. Forest research intitute's thinning experiments in Scots pine forests. (Skogsförsöksanstaltens gallringsförsök i tallskog). - Reports of the Swedish Institute of Experimental Forestry, 29, 1-169. (In Swedish).

Padari, A. 1994. Principles of selecting height/ diameter curves. (Kõrguse kõverate valiku põhimõtted). - Teadustööde kogumik, 173, 134-143. (In Estonian).

Padari, A., Metslaid, S., Kangur, A., Sims, A., Kiviste, A. 2009. Modelling stand mean height in young naturally regenerated stands - a Case Study in Järvselja, Estonia. - Baltic Forestry, $15,226-236$

Peschel W. 1938. The mathematical methods for deriving the growth laws of trees and stands and the results of their application. (Die mathematischen Methoden zur Herleitung der Wachstumsgesetze von Baum und Bestand und die Ergebnisse ihrer Anwendung). Tharandter Forstliches Jarbuch, 89, 169-274.

Picard, N., Magnussen, S., Banak, L.N., Namkosserena, S., Yalibanda, Y. 2010. Permanent sample plots for natural tropical forests: A rationale with special emphasis on Central Africa. - Environmental Monitoring and Assessment, 164, 279-295.

Pinheiro, J.C., Bates, D.M. 2000. Mixed-Effects Models in S and SPLUS. New York, Springer. $528 \mathrm{pp}$.
Pretzsch, H. 2009. Forest Dynamics, Growth and Yield: From Measurement to Model. Berlin, Springer. $664 \mathrm{pp}$

Räty, M., Kangas, A.S. 2019. Effect of permanent plots on the relative efficiency of spatially balanced sampling in a national forest inventory. - Annals of Forest Science, 76, 20.

Sims, A., Kiviste, A., Hordo, M., Laarmann, D., Gadow, K. 2009. Estimating tree survival: a study based on the Estonian Forest Research Plots Network. - Annales Botanici Fennici, 46, 336-352.

Sims, A., Mändma, R., Laarmann, D., Korjus, H. 2014. Assessment of tree mortality on the Estonian Network of Forest Research Plots. - Forestry Studies / Metsanduslikud Uurimused, 60, 57-68.

Sharma, M., Amateis, R., Burkhart, H. 2002. Top height definition and its effect on site index determination in thinned and unthinned loblolly pine plantations. - Forest Ecology and Management, 168, 163-175.

Sharma, R.P. 2009. Modelling height-diameter relationship for Chir pine (Pinus roxberghi) trees. - Banko Janakari, 19(2), 3-9.

Skovsgaard, J.P. 2008. Analysing effects of thinning on stand volume growth in relation to site conditions: A case study for even-aged Sitka spruce (Picea sitchensis (Bong.) Carr.). Forestry: An International Journal of Forest Research, 82, 87-104.

Tomé, M., Soares, P., Barreiro, S., Iciar, A., Bollandsås O. M., Cañellas. I., Eid, T., Kiviste, A., Marušák, R., Moreno-Fernandez, D., Orazio, C., Spiecker, H., Socha, J., Skovsgaard J. P., Zasada M., Corona, P. 2019. Standardization of symbols for forest variables used in forest assessment and modelling. - Brazilian Journal of Forestry Research, 39, 768.

van Laar, A., Akça, A. 1997. Forest Mensuration. Dordrecht, Springer. 385 pp.

Vanclay, J.K., 1994. Modelling Forest Growth and Yield: Applications to Mixed Tropical Forests. New York, CABI. 312 pp.

Weiskittel, A.R., Hann, D.W., Hibbs, D.E., Lam, T.Y., Bluhm, A.A. 2009. Modeling top height growth of red alder plantations. - Forest Ecology and Management, 258, 323-331.

West, P.W. 2009. Tree and Forest Measurement. Cham, Springer. 214 pp.

Zhang, S., Chen, C., He, S., Wu, K., Zhan, Y. 2008. Natural thinning and structural patterns of intermediate cutting intensity in a Cunninghamia lanceolata stand. - Frontiers of Forestry in China, 3, 254-263. 


\title{
Keskmine kõrgus või domineeriv kõrgus - mida eelistada Eesti puistute kõrguskasvu modelleerimisel?
}

\author{
Toomas Tarmu, Diana Laarmann ja Andres Kiviste
}

\section{Kokkuvõte}

Ulatuslik andmete hulk, nende kogumise metoodika, järjepidevus ja korrektsus loovad eeldused senisest usaldusväärsemate metsa mudelite koostamiseks Eesti kohta. Metsa kasvu uurimisel peetakse kõige väärtuslikumaks andmete kogumise allikaks kordusmõõdetavaid metsa püsiproovitükke. Selles uurimuses kasutatakse Eestit katvat metsa kasvukäigu püsiproovitükkide võrgustiku (KKPRT) andmeid, mille mahukus võimaldab teha üldistusi Eesti metsa kasvumudelite kohta. Uurimuse eesmärgiks oli analüüsida domineeriva kõrguse (ülakõrguse) kasutamise võimalust alternatiivina keskmisele kõrgusele puistu kasvu mudelites ning hinnata mudelprognooside täpsust harvendusraie mõjul Eesti metsades. Uurimuse hüpotees oli, et puistu keskmine kõrgus on harvendusraiega mõjutatud rohkem kui domineeriv kõrgus.

Eesti metsanduslikus praktikas kasutatakse puistu kõrgusena keskmist kõrgust, mis on oluliseks muutujaks metsamajanduslikes normatiivides ja mudelites. Paljudes maades kasutatakse puistu kõrgusena keskmise kõrguse asemel domineerivat kõrgust. Erinevates maades defineeritakse domineerivat kõrgust erinevalt. Käesolevas artiklis on defineeritud domineeriv kõrgus vastavalt IUFRO terminoloogiale kui 100 suurima puu keskmine kõrgus hektari kohta. Kuigi IUFRO terminoloogia ei täpsustata, kas suurima puu identifikaatorina tuleks kasutada puu kõrgust või läbimõõtu, kasutasime käesolevas uurimises põhjamaade eeskujul domineerivat kõrgust kui 100 suurima läbimõõduga puu keskmist kõrgust hektari kohta.
Kasvava metsa mõõtmise üldise metoodika järgi mõõdetakse proovitükil kõigi puude rinnasläbimõõt, kuid kõrgus vaid mudelpuudel. Optimaalse kõrguskõvera leidmiseks testiti viit erinevat mudelit, millest sobivaimaks osutus Artur Nilsoni loodud mudel (6).

Puistu kõrguskasvu uurimiseks koostati proovitükkide paarikaupa järjestikuste mõõtmiste andmestik. Iga paarismõõtmise korral arvutati proovitüki takseertunnused mõõtmisperioodi alguses ja lõpus ning perioodi jooksul tehtud raie ja loodusliku suremuse mahud. Puistu keskmise kõrguse kasvumudeliks kasutati Eesti riigimetsakorralduse takseerkirjelduste andmeil loodud diferentsmudelit (7) ja domineeriva kõrguse kasvumudeliks Rootsi Põllumajandusülikooli männikute püsiproovitükkide andmeil loodud diferentsmudelit (8). Iga mõõtmisperioodi jaoks arvutati perioodi algusandmete põhjal mudelite (7) ja (8) prognoosid perioodi lõpuks ning prognoosivead proovitüki andmete ja mudelprognooside vahena.

Uuringu tulemusel selgus, et keskmise kõrguse prognoosiviga oli suurem kui domineeriva kõrguse prognoosiviga sel juhul, kui perioodi jooksul toimus harvendusraie. Kui kahe järjestikuse mõõtmise vahel harvendusraiet ei toimunud, siis domineeriva kõrguse metsakasvu mudeli (8) prognoosiviga oli ligikaudu sama mis keskmise kõrguse kasvumudeli (7) korral.

Uurimuse käigus loodi regressioonimudel (9), mida saab kasutada peapuuliigi domineeriva kõrguse arvutamiseks teiste takseertunnuste kaudu (keskmine kõrgus, ruutkeskmine läbimõõt ja puude arv hektaril) jääkstandardhälbega 0,47 m. 